



\section{Digitized by the Internet Archive in 2011 with funding from University of Toronto}





\section{CONTRIBUTIONS}

\section{OF THE}

ROYAL ONTARIO MUSEUM OF ZOOLOGY AND PALAEONTOLOGY

No. 38

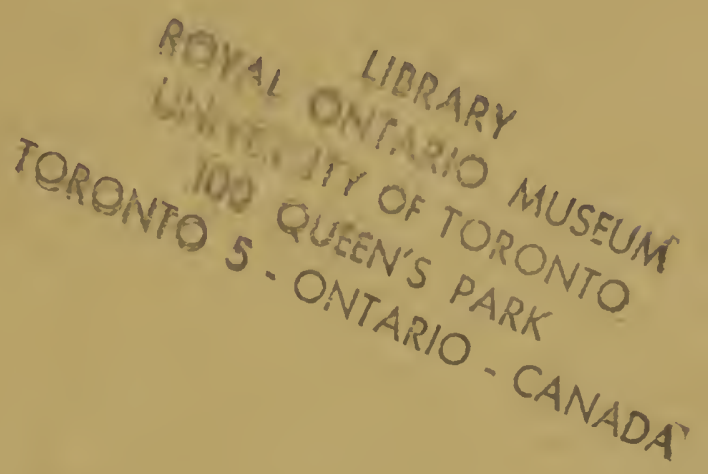

\section{TAXONOMIC STATUS OF THE EUROPEAN} HARE IN ONTARIO

By

Randolph L. Peterson and J. K. Reynolds 



\title{
TAXONOMIC STATUS OF THE EUROPEAN HARE IN ONTARIO
}

\author{
by
}

\section{Randolph L. Peterson and J. K. Reynoldo ${ }^{*}$}

The present population of European hares in southern Ontario apparently resulted from an introduction of nine animals near Brantford, Ontario, in 1912. These were secured from a German zoological exporter and the exact source of this introduced stock is not known. In the first published account of this introduction Dymond (1922) concluded that the species was Lepus europaeus and he inferred that it probably represented the race $L$. e. europaeus Pallas.

A year later Anderson (1923) added further notes concerning the status of this hare in Ontario, but carefully avoided using a subspecific name, pointing out the difficulties in making a definite identification with the limited amount of material available. The following year Miller (1924) listed L. e. europaeus as the form resident in Ontario and cited only Anderson (1923), not Dymond (1922). In the same year Silver (1924) reviewed the introductions into the United States, indicating that most of the original stock released there came from Hungary. It was not until eleven years later that Goodwin (1935) checked the identity of the New England introductions and showed that on the basis of the source of the stock, its coloration and large hind feet, the animal then occurring there was L. e. hybridus Desmarest.

Later Anderson (1947) followed Miller (1924) and Cross and Dymond (1929) in ascribing the name L. e. curopaeus to the Ontario populations, but he cited only himself (1923) for the previous history of the form in Ontario. Downing (1948) and others have used the same name.

In his recent synopsis of the North American Lagomorpha, Hall (19.51) lists both europaeus and hybridus. Citing Goodwin (1935), he restricts hybridus to the United States from New York eastward; following Anderson (1947), he refers the populations of Ontario and Michigan to europaeus. He cites Burt (1946) in defining the range of this hare in Michigan, although Burt did not employ a trinomial in his discussions of this species in Michigan.

Miller (1924) provides a diagnosis of the races in question, indicating that europaeus occurs in Denmark, through most of Germany and central France, and into Switzerland, while hybridus ranges from

'Ontario Department of Lands and Forests, Maple, Ontario. 
eastern Germany eastward into central Russia. Ellerman and MorrisonScott (1951) follow Miller with virtually the same definition of ranges for these two subspecies.

Reynolds (1952) found that specimens examined by him did not conform to Miller's (1912) diagnosis of L. e. europaeus but he was unable to examine the necessary comparative material in order to settle this point. One skin and two skulls of $L$. e. europaeus from France in the Royal Ontario Museum of Zoology and Palaeontology proved to be so noticeably distinct from the Ontario examples of European hares that attempts were made to locate more European material in order to clarify the identity of the Ontario specimens.

We wish to acknowledge the cooperation of the following persons and institutions (the latter followed by abbreviations to be used in the text) in placing specimens at our disposal: Dr. G. H. H. Tate, American Museum of Natural History (A.M.N.H.); Dr. C. P. Lyman, Museum of Comparative Zoology (M.C.Z.); and Drs. D. S. Johnson and H. W. Setzer, United States National Museum (U.S.N.M.).

\section{Pelage}

Ontario specimens conform with Miller's (1924) diagnosis of hybridus. Compared with L. e. europaeus from France and Germany (winter pelage), they have more extensive white markings on the side of the head and the whitish area below the eye is usually continuous with that of the throat. The rump is more contrastingly grey in colour, with its median area only slightly darker, whereas in europaeus the dark colour of the back extends to near the base of the tail. Although there is considerable variation in general coloration of the body in both races, hybridus averages lighter.

One specimen, from Halton County, Ontario, taken on January 28, 1932, is of particular interest. Although it has maintained faint suggestions of the normal colour pattern, the entire back, feet, and ears are pale greyish. The back has a diluted admixture of white and buff, the feet, legs and sides are slightly more buffy, and the ears are more greyish with dark grey tips. The upper side of the tail and crown of the head are also darker grey. The lower sides and underparts are almost entirely white, although the throat has a few scattered buffy hairs. At present we are not familiar with the grey winter pelage which hybridus is said to assume "habitually". The above specimen is the only one of its type we have seen and we are unable to say whether it represents the grey pelage referred to by Miller (1924) or a colour mutation.

A specimen from near Leningrad, Russia (M.C.Z. No. 25351), taken on December 6,1886, has light greyish colour extending well up on its sides, behind the ears, and down on to the upper portion of the front and hind limbs. This light area joins the broad greyish rump, restricting the dark back colour to a relatively small area along the 


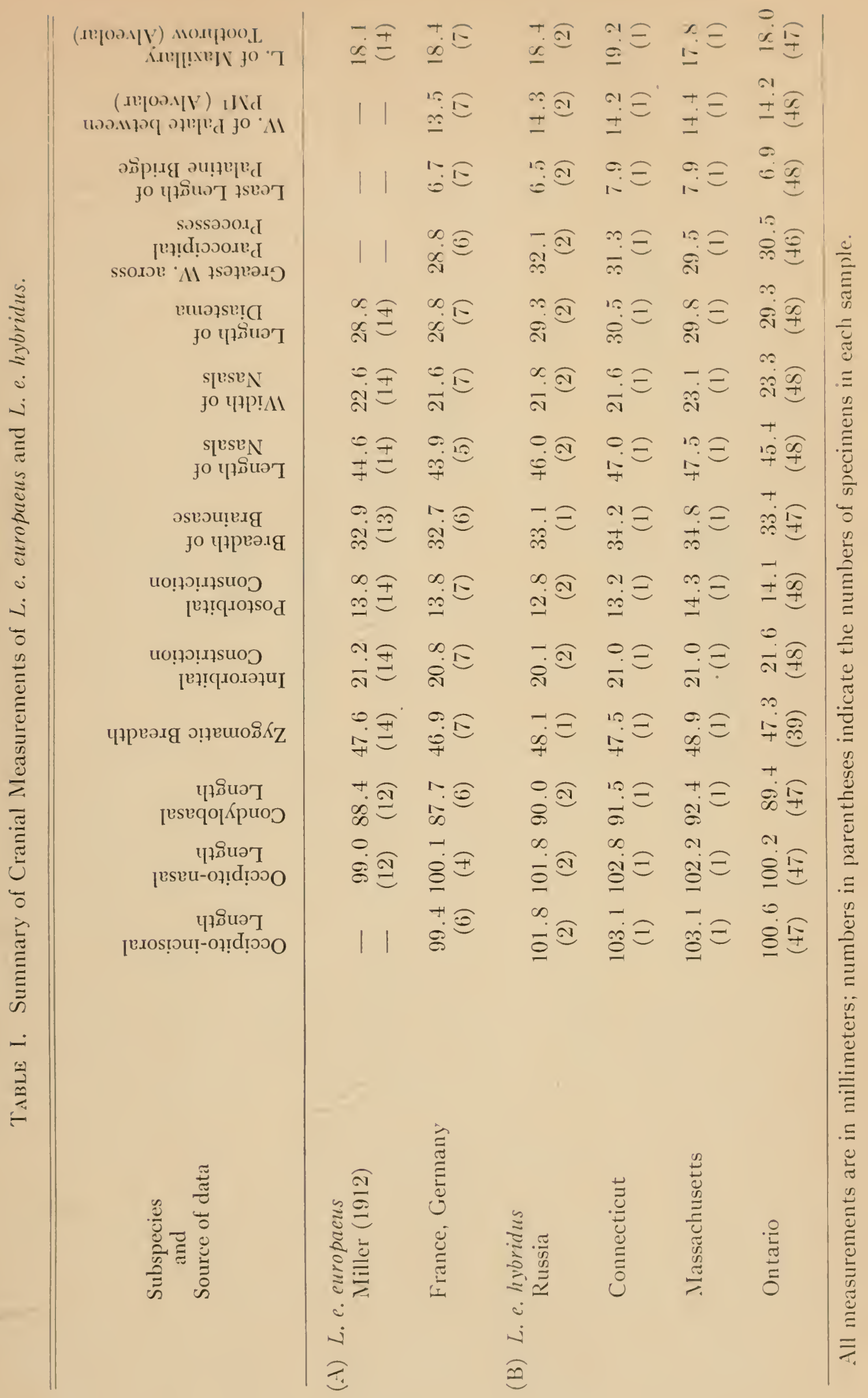




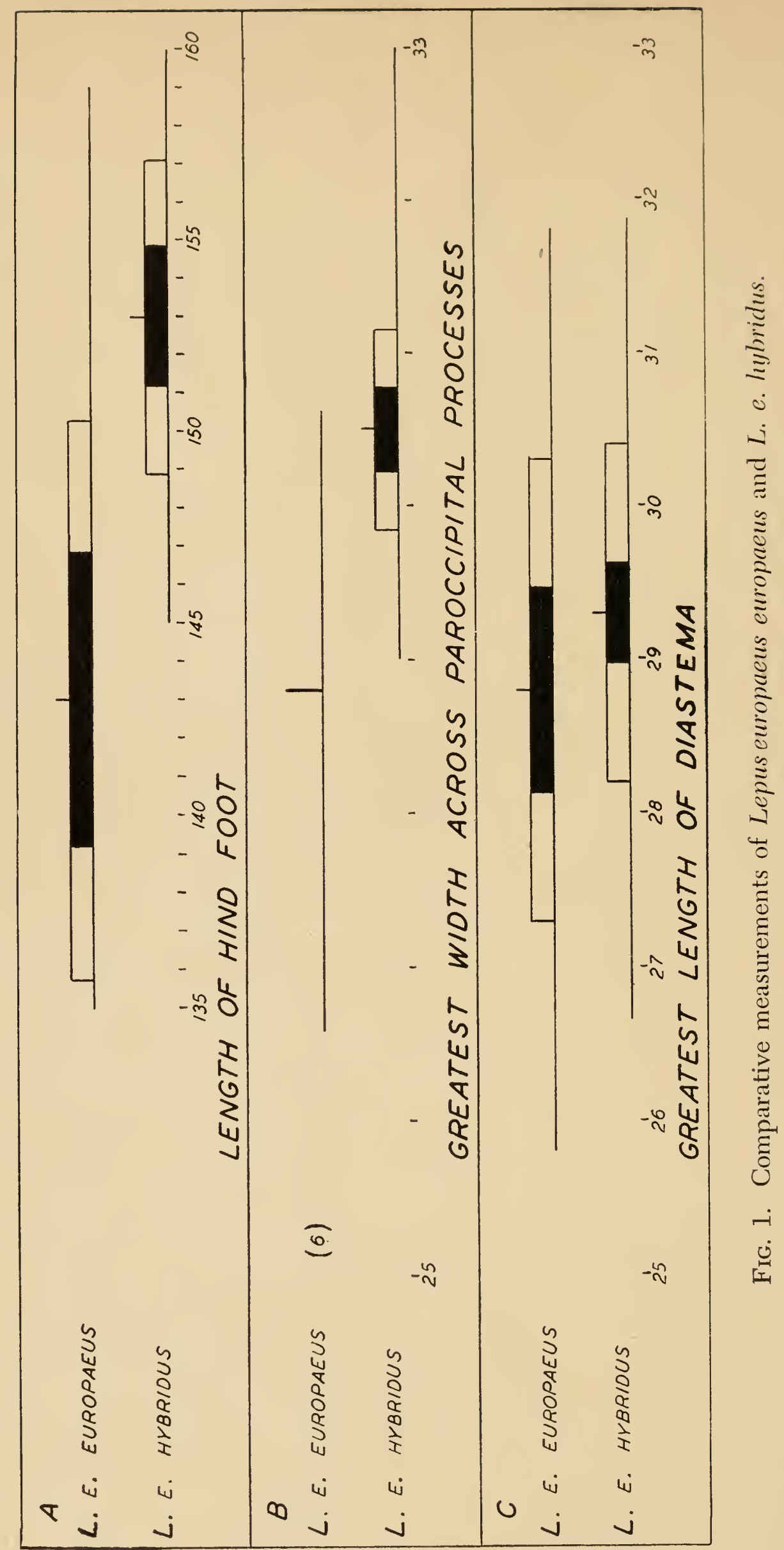


middle of the back. The under fur of the rump is greyish, while that of the remaining light area is more buffy. The colour of the underparts, feet, head, cars, tail, and central region of the back are essentially the same as most Ontario specimens except that the rump is noticeably lighter. We find that one specimen each from Daghestan, Caucasus, near Petrovsk, Russia; Washington, Comnecticut; and North Adams, Massachusetts (all from M.C.Z.) are indistinguishable from specimens of L. e. hybridus from Ontario.

\section{Crantal Measurements}

The cranial measurements of available specimens of L. e. europaeus and $L$. $\mathcal{C}$. hybridus were compared with similar measurements presented by Miller (1912) and with those of Ontario specimens. These data, summarized in Table I, suggest that the skulls of europaeus differ from those of hybridus in having a narrower width across the paroccipital processes. In the former this width is usually about equal to the length of the diastema, while in the latter the greatest width of the paroccipital processes is usually greater than the length of the diastema. These comparisons are presented graphically in Fig. 1 ( $B$ and C), using the method of Hubbs and Hubbs (1953). A summary of the cranial measurements of the skulls of 48 specimens of L. e. hybridus from Ontario is given in Table II(A).

\section{Gross Measurements}

Miller (1912) has drawn attention to the greater size of the hind foot of L. e. hybridus compared with that of L.e. europaeus. In comparing the gross measurements of Ontario specimens with those of L. e. europaeus we found that this difference is statistically significant (Fig. 1(A)). The measurements of Ontario specimens are summarized in Table II (B).

It has been stated (Anon. 1947) and is widely held among hunters in Ontario that the European hares here sometimes attain a weight of twenty pounds or more. In the course of handling 973 specimens, however, Reynolds (1952) found only four which exceeded $5000 \mathrm{gm}$. (about eleven pounds). The largest weighed $5600 \mathrm{gm}$. (about twelve and one-half pounds ).

\section{Specimens Examined}

Unless otherwise indicated, specimens are in the Royal Ontario Museum of Zoology and Palaeontology. Lepus e. europaeus-a total of 14, as follows: France: Bretigny, 1; near Cadillac, Gironde, 1; Gironde, 1; 2 mi. NE Is-Sor-Tile, Cote-d’Or, 1 (U.S.N.M.); Poiseul-laGrange, Cote-d'Or, 1 (A.M.N.H.). Germany: near Hamburg, 6 (A.M.N.H.); Magdeburg, I (U.S.N.M.). Switzerland: Werdenberg, St. Gallen, 1 (U.S.N.M.); Wittenbach, St. Gallen, 1 (U.S.N.M.). Lepu.s e. hybridus-a total of 82, as follows: Russia: near Leningrad, I 
TABLE II. Measurements of $L$. e. hybridus from southern Ontario.

\begin{tabular}{|c|c|c|c|c|}
\hline Dimension & $\begin{array}{l}\text { Number of } \\
\text { Specimens }\end{array}$ & $\begin{array}{l}\text { Mean } \\
(\mathrm{mm} .)\end{array}$ & $\begin{array}{l}\text { Standard } \\
\text { Deviation }\end{array}$ & $\begin{array}{l}\text { Standard } \\
\text { Error }\end{array}$ \\
\hline \multicolumn{5}{|l|}{ (A) Cranial Measurements } \\
\hline Occipito-incisoral length & 47 & 100.6 & 2.0 & 0.29 \\
\hline Occipito-nasal length & 47 & 100.2 & 2.2 & 0.33 \\
\hline Condylobasal length & 47 & 89.4 & 2.0 & 0.29 \\
\hline Zygomatic breadth & 39 & 47.3 & 1.4 & 0.23 \\
\hline Interorbital constriction & 48 & 21.6 & 1.4 & 0.20 \\
\hline Postorbital constriction & 48 & 14.1 & 1.1 & 0.16 \\
\hline Breadth of braincase & 47 & 33.4 & 1.1 & 0.16 \\
\hline Length of nasals & 48 & 45.4 & 2.0 & 0.29 \\
\hline Width of nasals & 48 & 23.3 & 1.5 & 0.21 \\
\hline Diastema & 48 & 29.3 & 1.1 & 0.16 \\
\hline \multicolumn{5}{|l|}{ Greatest width across } \\
\hline paraoccipital processes & 46 & 30.5 & 0.9 & 0.13 \\
\hline Least length of palatine bridge & 48 & 6.9 & 0.6 & 0.09 \\
\hline Width of palatine bridge & & & & \\
\hline $\begin{array}{l}\text { (Alveolar) } \\
\text { Length of maxillary toothrow }\end{array}$ & 48 & 14.2 & 0.8 & 0.12 \\
\hline (Alveolar) & 47 & 18.0 & 0.6 & 0.09 \\
\hline \multicolumn{5}{|l|}{ (B) Gross Measurements } \\
\hline Total length-R.O.M.Z.P. & 23 & 652 & 22.4 & 4.8 \\
\hline Reynolds (1952) & 260 & 681 & 24.2 & 1.5 \\
\hline Tail-R.O.M.Z.P. & 19 & 100 & 5.4 & 1.2 \\
\hline Reynolds (1952) & 260 & 92 & 9.8 & 0.6 \\
\hline Hind Foot-R.O.M.Z.P. & 22 & 153 & 4.1 & 0.9 \\
\hline Reynolds (1952) & 260 & 151 & 4.6 & 0.3 \\
\hline Ear from Crown-Reynolds & 260 & 123 & 3.6 & 0.2 \\
\hline Ear from Notch-R.O.M.Z.P. & 4 & 98 & 2.2 & 1.1 \\
\hline Weight (gm.) 一 Reynolds (1952) & 693 & 4180 & 380 & 15 \\
\hline
\end{tabular}

(M.C.Z.); Daghestan, Petrovsk, Caucasus, 1 (M.C.Z.). Connecticut: Washington, 1 (M.C.Z.). Massachusetts: near North Adams, 1 (M.C.Z.). Ontario: Brant Co.-Dumfries South Twp., 1; Scotland, 2; Halton Co. $-2 \%$ mi. N. Trafalgar, 1; Middlesex Co.-Duncrief, 4; Ilderton, 1; Komoka, 1; Lobo Twp., 14; McGillivray Twp., 8; Oxford Co.-Blenheim Twp., 1; Kintore, 20; Oxford East Twp., 1; Woodstock, 2; Parry Sound District-Burk's Falls, 1; Perth Co.-Mornington Twp., 5; Victoria Co.-Lindsay, 1; Waterloo Co.-Centreville, 1; Galt, 1; Kitchener, 3; Wilmot Twp., 1; Wellington Co.-Puslinch, 1; York Co.King, 3; Nobleton, 1; Pottageville, 1; Toronto, 1; Vaughan Twp., 1; Woodbridge, 1. 


\section{SUMMARY}

The European hare, introduced in 1912 and now established in southern Ontario, appears to belong to the race Lepus europaeus hybridus Desmarest.

\section{Literature Citeid}

Anderson, R. M.

1923. Further notes on the European hare in Ontario. Can. Field-Nat., vol. 37, no. 4, pp. 75-76.

1947. Catalogue of Canadian Recent mammals. Natl. Mus. Can., Bull. no. 102 (Biol. Ser. no. 31), pp. 1-238.

\section{Anonyinous}

1947. "Letters to the Editor". Hunting and Fishing in Canada, vol. 13,

BurT, W. H. no. 10, p. 44.

1946. The mammals of Michigan. Univ. Mich. Press, Ann Arbor, pp. 1-288.

Cross, E. C. And J. R. Dyirond

1929. The mammals of Ontario. Roy. Ont. Mus. Zool. Handbook no. 1, pp. $1-55$.

Downing, S. C.

1948. A provisional check-list of the mammals of Ontario. Roy. Ont. Mus.

DYMoND, J. R. Zool. Misc. Pub. no. 2, pp. 1-11.

1922. The European hare in Ontario. Can. Field-Nat, vol. 36, no. 5, pp. 142-143.

Ellerman, J. R. and T. C. S. Morrison-Scott

1951. Checklist of Palaearctic and Indian mammals, 1758 to 1946. Brit. Mus. (Nat. Hist.), pp. 1-810.

Goodwin, G. G.

1935. The mammals of Comnecticut. Comn. State Geol. and Nat. Hist.

HaLL, E. R. Survey, Bull. no. 53, pp. 1-221.

1951. A synopsis of the North American Lagomorpha. Univ. Kans. Pub. Mus. Nat. Hist., vol. 5, no. 10, pp. 119-202.

Hubbs, C. L. And C. HubBs

1953. An improved graphical analysis and comparison of series of samples. Syst. Zool., vol. 2, no. 2, pp. 49-56, 92.

Miller, G. S., Jr.

1912. Catalogue of the mammals of western Europe. Brit. Mus. (Nat. Hist.), pp. 1-1091.

1924. List of North American Recent mammals, 1923. U.S. Nat. Mus,, Bull. no. 128, pp. 1-673.

REyNolds, J. K.

1952. The biology of the European hare (Lepus europaeus Pallas) in southwestern Ontario. Unpub. Ph.D. Thesis, Univ. Western Ontario, $265 \mathrm{pp}$.

Silver, J.

1924. The European hare (Lepus europaeus) in North America. Journ. Agri. Res., vol. 28, no. 11, pp. 1133-1137. 



$$
\text { · }
$$
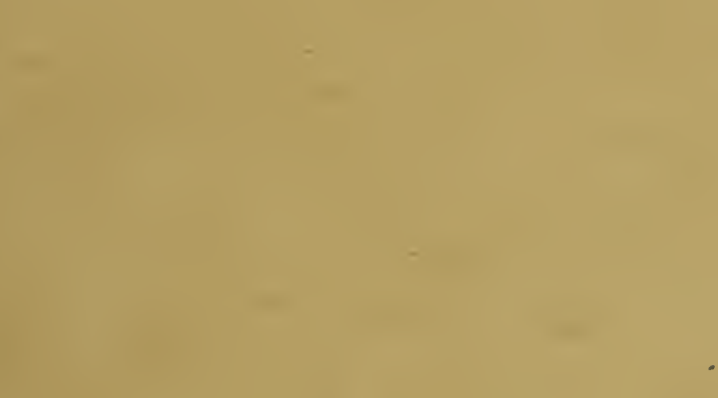

.

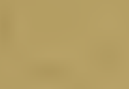

$=$

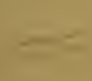





LIBRARY

ROYYAL ONTARIO MUUSEUM 
